\title{
Determining the lithogeochemical background concentrations of 39 elements in Bavarian rocks
}

Bernhard Wagner ( $\sim$ bernhard.wagner@lfu.bayern.de )

Bavarian Environment Agency https://orcid.org/0000-0003-4194-6604

Anneke Tammen

Environment Agency of Bavaria

Dietmar Jung

Environment Agency of Bavaria

\section{Research Article}

Keywords: Lithogeochemical background, Rock properties, Heavy metals, Geostatistics, Geological Map, Bavaria

Posted Date: August 3rd, 2021

DOI: https://doi.org/10.21203/rs.3.rs-695646/v1

License: @ (i) This work is licensed under a Creative Commons Attribution 4.0 International License.

Read Full License

Version of Record: A version of this preprint was published at Environmental Earth Sciences on March 24th, 2022. See the published version at https://doi.org/10.1007/s12665-022-10334-8. 


\title{
Determining the lithogeochemical background concentrations of 39 elements in Bavarian rocks
}

\author{
Bernhard Wagner ${ }^{1}$, Anneke Tammen ${ }^{1}$, Dietmar Jung ${ }^{1}$ \\ ${ }^{1}$ Bavarian Environment Agency, Hof, Germany \\ E-Mail: bernhard.wagner@1fu.bayern.de
}

\begin{abstract}
Typical element background concentrations of rock units in Bavaria were evaluated by statistical means and presented in a lithogeochemical map, derived from the geological map at a scale of 1:25,000. The elements include 39 geogenic main and trace elements $\left(\mathrm{SiO}_{2}, \mathrm{Al}_{2} \mathrm{O}_{3}\right.$, $\mathrm{Fe}_{2} \mathrm{O}_{3}, \mathrm{MnO}, \mathrm{MgO}, \mathrm{CaO}, \mathrm{Na}_{2} \mathrm{O}, \mathrm{K}_{2} \mathrm{O}, \mathrm{TiO}_{2}, \mathrm{P}_{2} \mathrm{O}_{5} \mathrm{Li}, \mathrm{Be}, \mathrm{Sc}, \mathrm{V}, \mathrm{Cr}, \mathrm{Co}, \mathrm{Ni}, \mathrm{Cu}, \mathrm{Zn}, \mathrm{Ga}, \mathrm{As}$, Rb, Sr, Y, Zr, Nb, Mo, Cd , Sn , Sb , Cs , Ba , La , Ce , Tl , Pb , Bi , Th and U).

The distributions of element concentrations in the lithogeochemical units follow closely lognormal patterns in a large majority of cases. Statistical parameters (10th, 25th, 50th, 75th, 90th percentiles) of investigated elements were determined using the cenfit function of the NADA package within the open source program $\mathrm{R}$. The investigation, based on 8,838 analysed samples, provided data for about $2 / 3$ of the area of Bavaria. The lithogeochemical map with medians (50th percentiles) and background values (90th percentiles) of the investigated elements is available in a web map application. Thus, the regional geogenic background values of the investigated elements in Bavaria are publicly available for a large variety of applications.
\end{abstract}

Keywords: Lithogeochemical background, Rock properties, Heavy metals, Geostatistics, Geological Map, Bavaria

\section{Introduction}

Geochemical rock data are important for many applications. For example, element concentrations define a suitability of rocks as raw materials. Then, geochemical rock properties determine the chemical composition of groundwater. Subsequently, soil geochemical properties depend strongly on the chemical properties of underlying rocks. 
In Germany, soil protection laws require legal measures when soils or underlying rocks exceed defined concentration limits for contaminants. Therefore, it is important to differentiate whether potential pollutants are of geologic or anthropogenic origin, because natural exceedances of limit values are exempt from legal procedures.

The main objective of the study was to determine geological background values of inorganic trace elements for environmental purposes. A special attention was given to potential pollutants and their availability to users via a web application.

Medians and 90th percentiles of element concentrations are considered as robust parameters for geochemical distributions (Licht 2020). However, the scope of this study is limited to a regional scale; this is due to a small number of samples (i.e. 8,838 samples) covering a relatively small area of about 72,000 square kilometers, i.e. $10 \mathrm{~km}^{2} /$ sample (Demetriades et al. 2018). For that reason, regionalization of lithogeochemical background variation, within lithogeochemical units, was not adressed in this study.

In Bavaria, background values were determined for soils (Geuß et al. 2011) and groundwater (Wagner et al. 2011). First steps to determine background values for rocks, in parts of Bavaria at a scale 1:200,000, were made by Linhardt and Zarbok (2005). Similar studies were carried out in Poland (Zglobicki et al. 2011), for the European scale (Salminen et al. 2005; De Vos and Tarvainen 2006), and for Australia (Reimann and Caritat 2018).

This paper presents an approach to mapping lithogeochemical background concentrations of rocks, based on detailed geological maps $(1: 25,000)$ by the Geological Survey of Bavaria. The concluding data is accessible via a web map browser and a web map service.

\section{Material and methods}

\section{Lithogeochemical Map}

The lithogeochemical map of Bavaria was obtained from the geological map (1:25,000) of Bavaria. For this purpose, the mapped units of the geological map were joined into larger units containing one or more geological units. Criteria for the grouping of mapped units are similar lithological compositions, e.g. sandstones, mudstones or limestones are each grouped, based on the assumption, that the larger units will have a similar pattern of lithogeochemical composition. The resulting lithogeochemical map of Bavaria contains 184 units, assembled 
from about 2,500 units of the geological map. Fig. 1 shows the same section of the geological map with 14 units (Fig. 1a) and the resulting lithogeochemical map with 9 units (Fig. 1b).

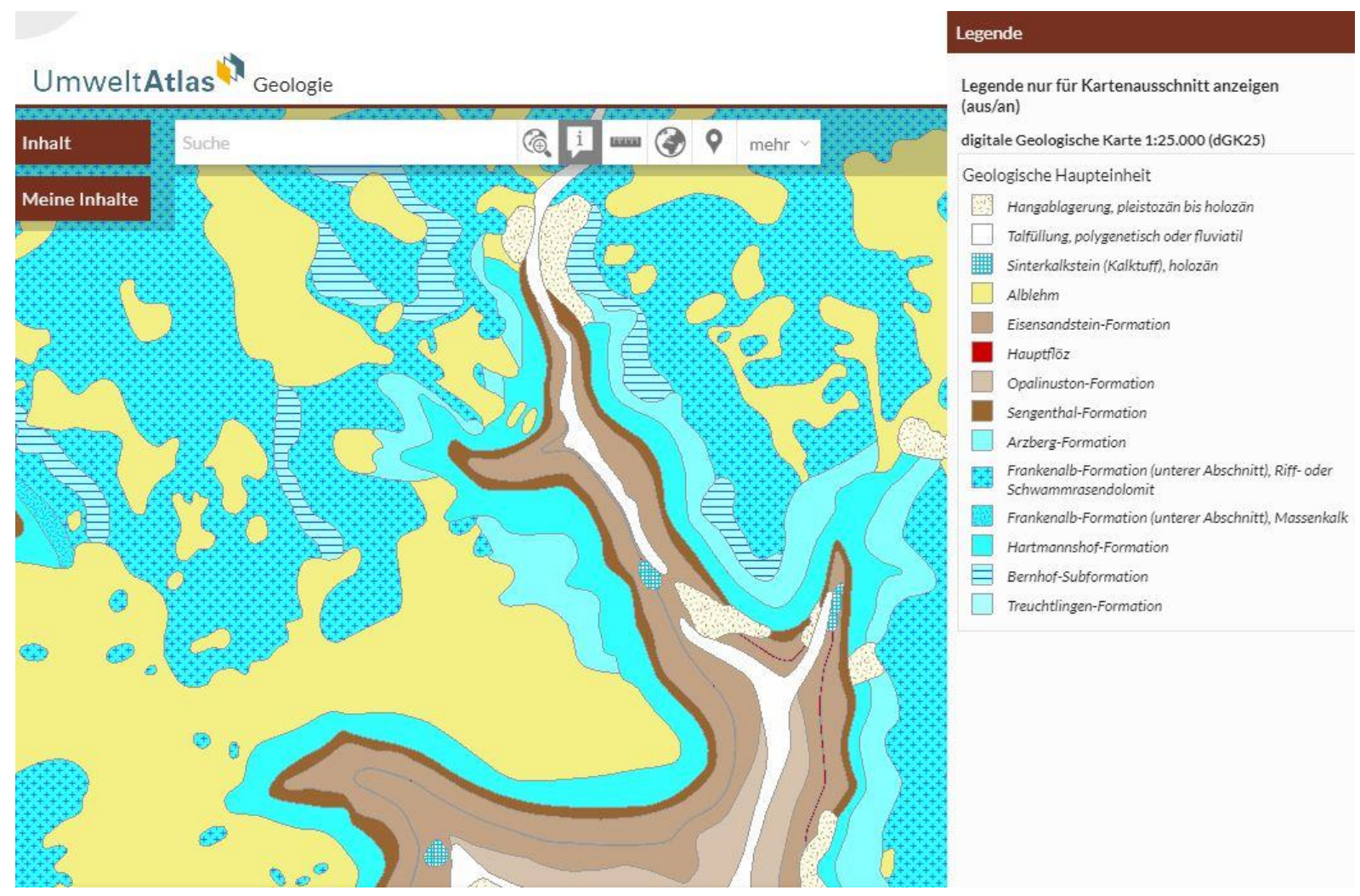

Fig. 1a

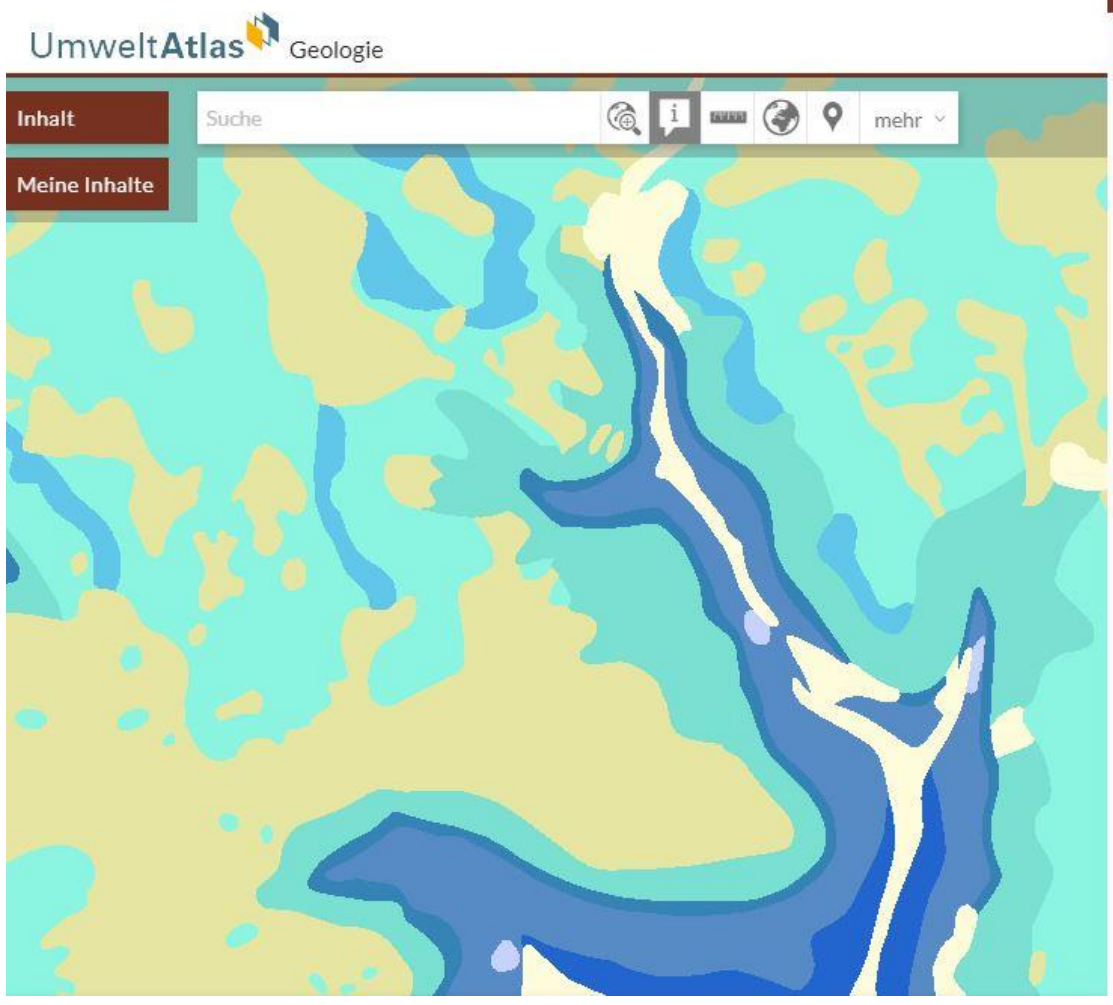

Legende nur für Kartenausschnitt anzeigen (aus/an)

digitale Lithogeochemische Karte 1:25.000 (dLGK25)

Kalkausfallung

Umlagerungsbildung

Alblehm

Bankkalk der Weißjura-Gruppe

Bank- und Plattendolomit der Weißjura-Gruppe

Massenfazies der WeißjJura-Gruppe

- Sengenthal-Formation

Eisensandstein-Formation

Feinsediment der Schwarz- und Braunjura-Gruppe 


\section{Fig. 1b}

Fig. 1: The same map section with the geological map containing 14 map units (a) and the lithogeochemical map, merged into 9 units (b) (extract from Bavarian Environmental Atlas www.umweltatlas.de).

\section{Sampling}

Sampling was carried out during mapping campaigns in the field as part of the geological survey, as well as from drill cores and reserve samples stored in the drill core archive of the Bavarian Geological Survey. The analytical data, used for the investigation, is stored in the Bavarian Soil Information System. All samples are assigned to the geological units of the geological map. Analysis data from 8.838 samples of the Bavarian rocks were available for the investigation.

\section{Laboratory Analysis}

The major elements were analysed by X-ray fluorescence analysis (XRF) of melt tablets. The following major elements were analysed: $\mathrm{SiO} 2, \mathrm{Al} 2 \mathrm{O} 3, \mathrm{Fe} 2 \mathrm{O} 3, \mathrm{MnO}, \mathrm{MgO}, \mathrm{CaO}, \mathrm{Na} 2 \mathrm{O}$, $\mathrm{K} 2 \mathrm{O}$, TiO2, P2O5. All other elements (mainly trace elements) were analysed by inductively coupled plasma mass spectrometry (ICP-MS): Li, Be, Sc, V, Cr, Co, Ni, Cu, Zn, As, Rb, Sr, Y, Mo, Cd, Sn, Sb, Cs, Ba, La, Ce, Tl, Pb, Bi, Th und U.

\section{Statistical analysis}

According to Helsel (2012) geochemical data are often normally or lognormally distributed. A simple approach to visualizing the distribution of large datasets is by probability plots (Lepeltier 1969; Sinclair 1976), where normally distributed data values lie on a straight line. Fig. 2 shows a typical lognormal distribution of arsenic concentrations in a lithogeochemical unit in the probability plot. No outliers were identified in this dataset. 


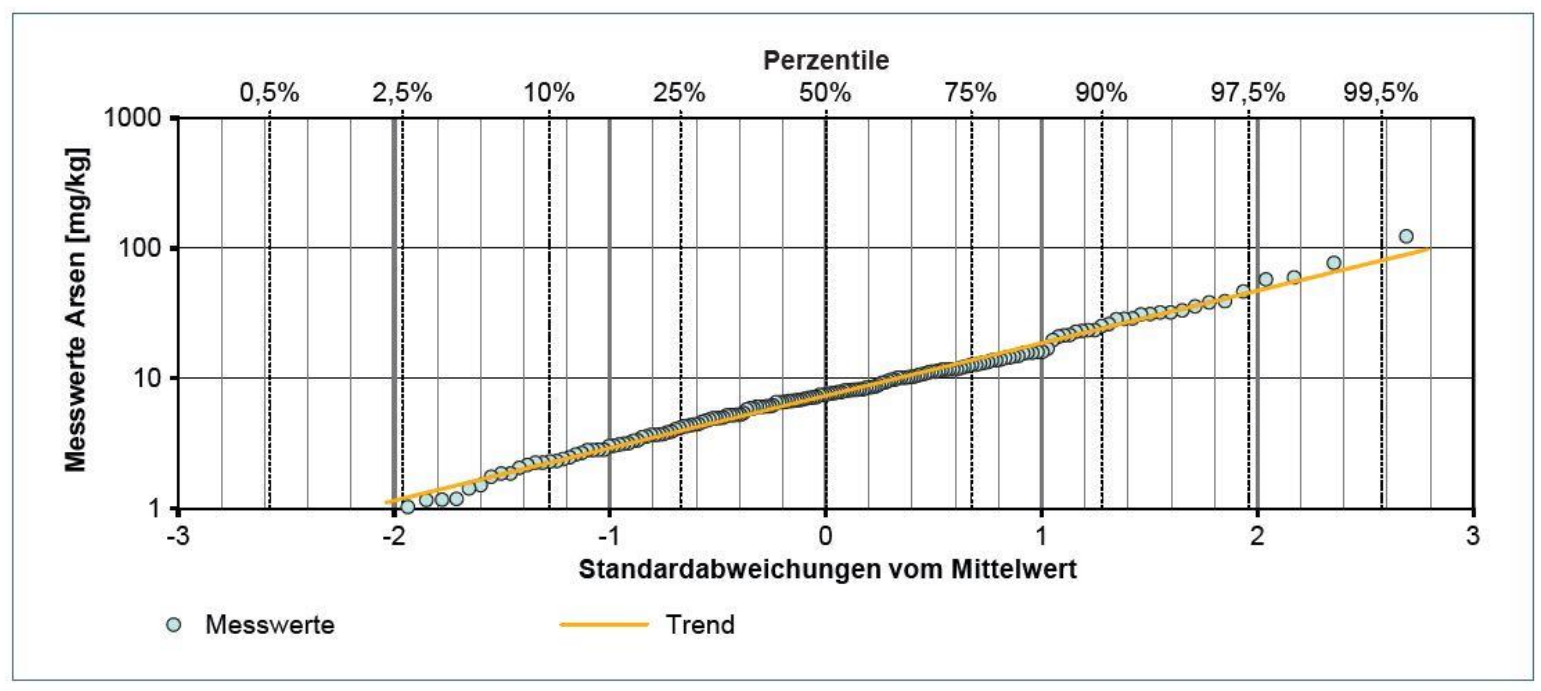

Fig. 2: Distribution of measured arsenic concentrations in the probability plot (from Tammen et al 2020).

All geochemical datasets were examined with respect to distribution patterns. Most distributions were rather close to normal or (predominantly) lognormal (left skewed) distributions. Based on visual inspection of the probability plot, any outliers were removed from the datasets. The distribution of element concentrations is represented by box-whisker plots. Several methods are available for determining statistical measures (i.e. 10th, 25th, 50th, 75th and 90th percentiles), such as Kaplan-Meier (KM), Maximum Likelihood Estimation (MLE) and Regression on Order Statistics (ROS) (Helsel 2012). In the study presented here, the KM method was used, which is implemented in the cenfit function of the R program. The analysis was performed only for datasets where at least $50 \%$ of the data were above the detection limit and more than 10 measured values were available.

\section{Results}

Statistical parameters were determined for 93 out of 184 lithogeochemical units, for which sufficient analyses were available. The area coverage of these units is about 2/3 of Bavaria. Trace elements could be evaluated in 54 lithogeochemical units with an area coverage of about $55 \%$. In order to make the data publicly available, the lithogeochemical map with the statistical measures of all investigated parameters is published as a web map service and in the web browser of the Bavarian Environment Agency:

https://www.umweltatlas.bayern.de/mapapps/resources/apps/lfu_geologie_ftz/index.html 
Due to the large number of elements investigated, only details for the trace elements arsenic, chromium, nickel and copper are presented below. Fig. 3 shows the box-whisker-plots for these elements.
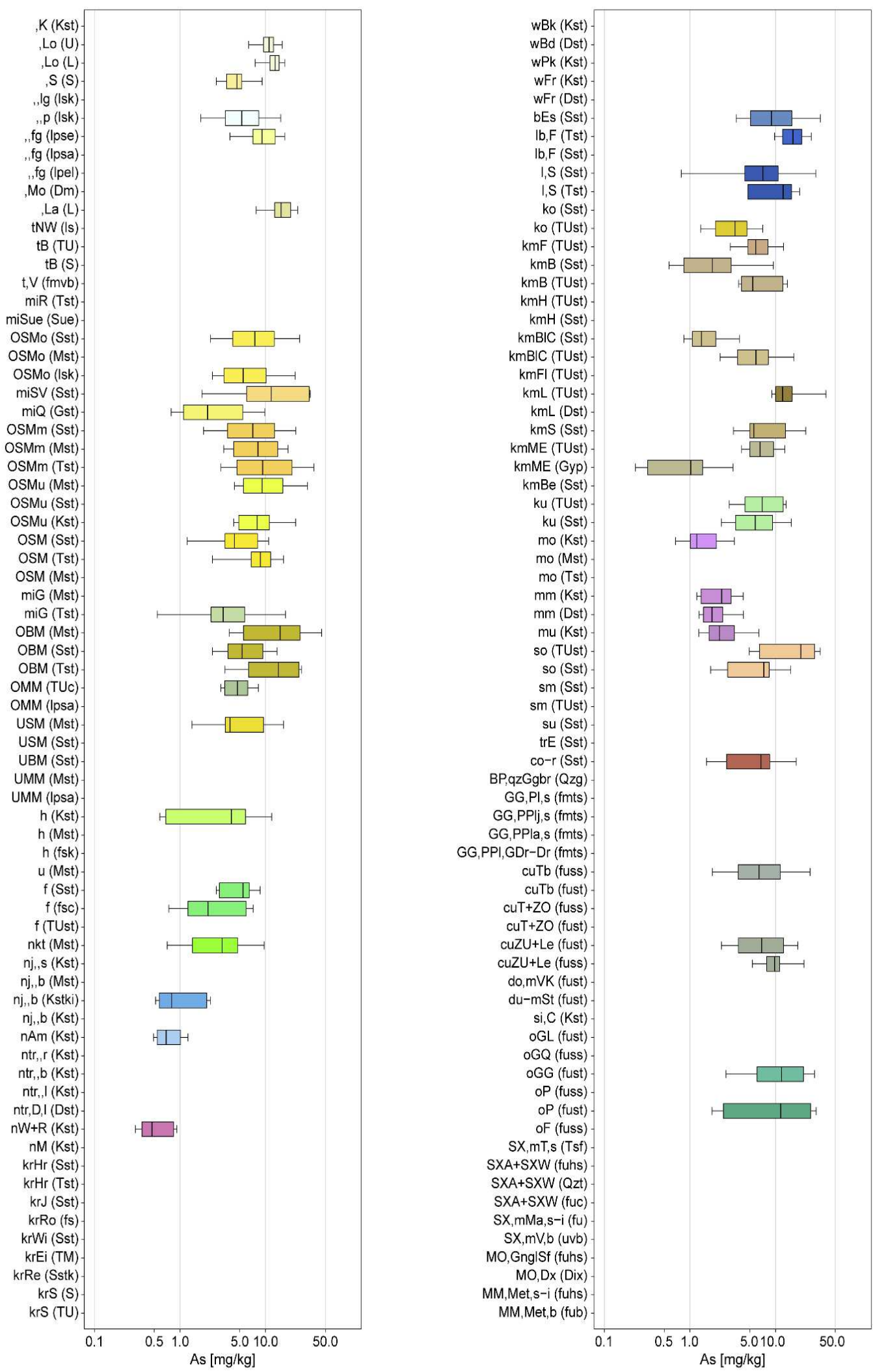

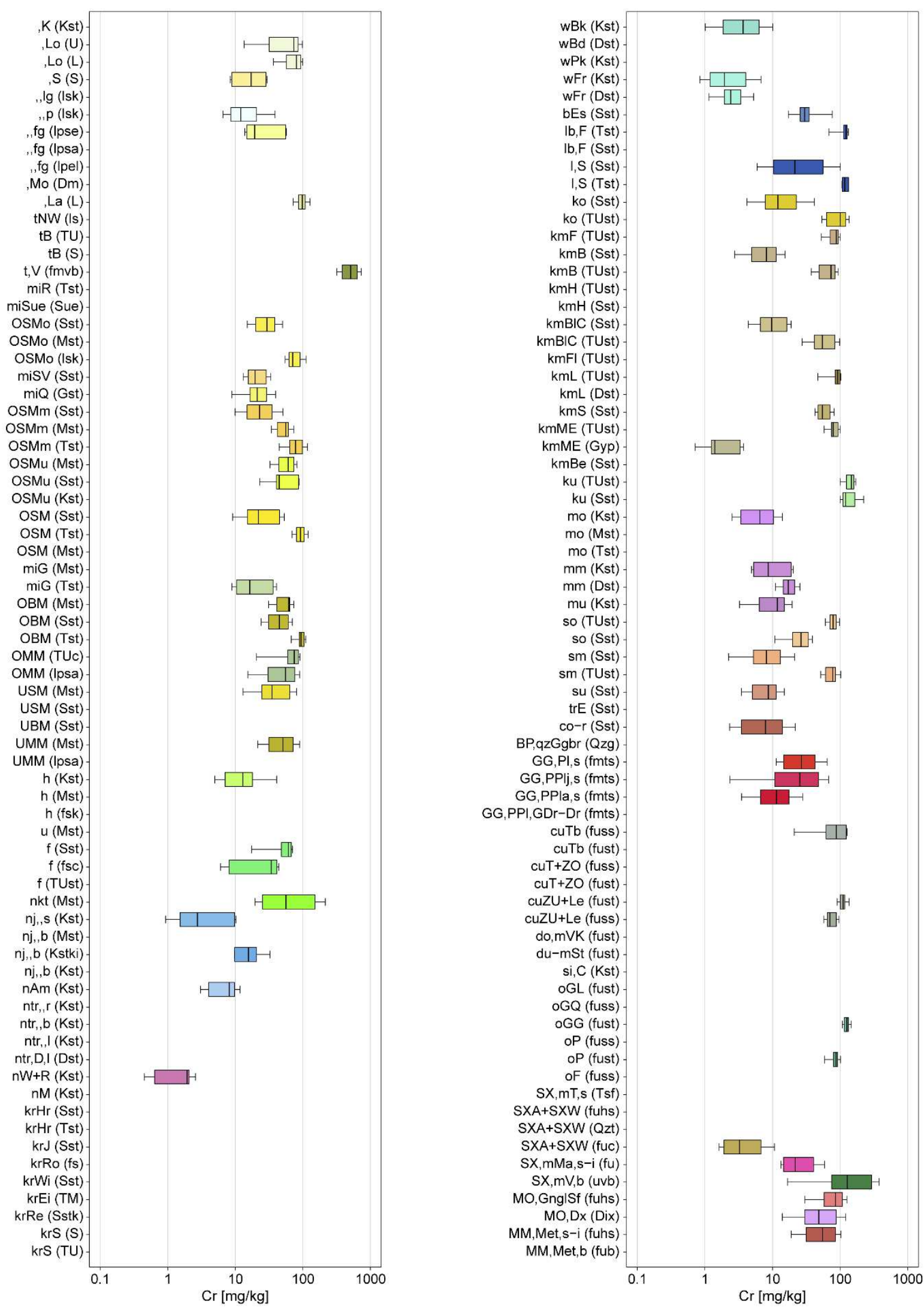

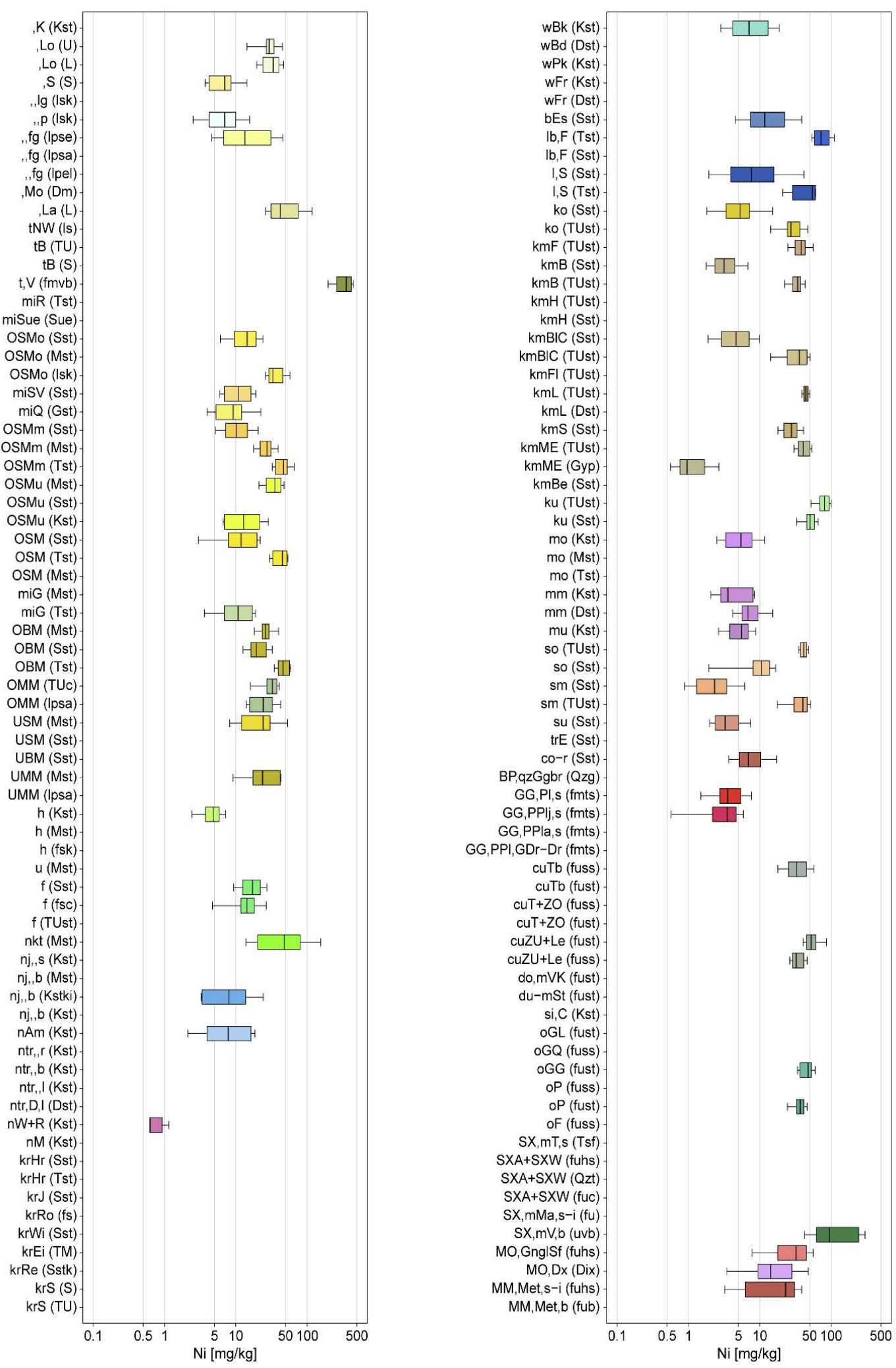

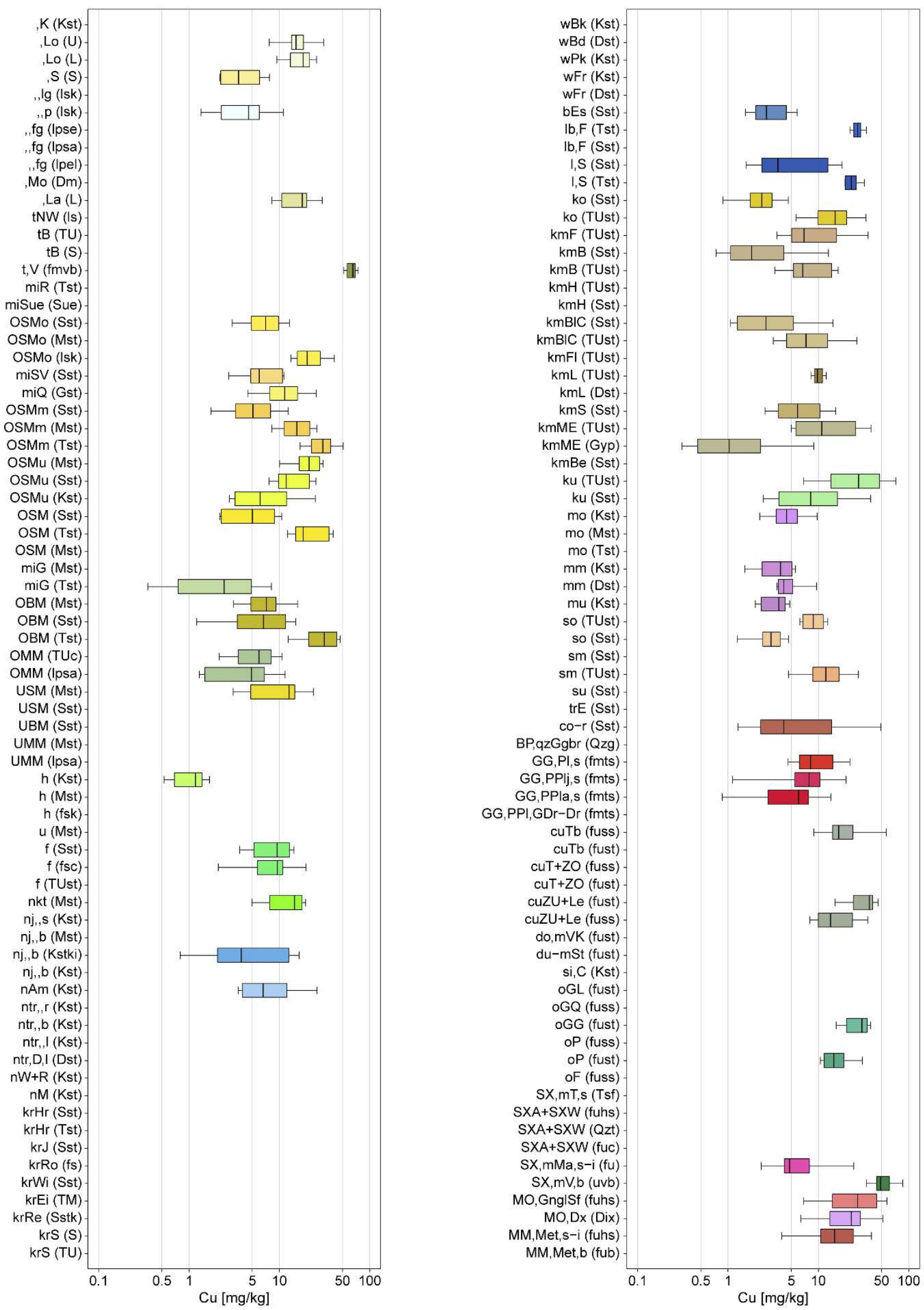

Fig. 3: Box-whisker plots of selected trace elements (arsenic, chromium, nickel and copper) for the 184 lithogeochemical units of Bavaria (main lithology in brackets). Blanks are units without evaluation. For the abbreviations of lithogeochemical units and lithologies (in parentheses), see Tammen et al. (2020). 
Figs. 4 and 5 show map views of the same trace elements representing concentration classes of background (90th percentile) and median (50th percentile) values of the surface rocks of Bavaria, respectively. Blank areas represent the lithogeochemical units that could not be evaluated due to a lack of analysis samples.

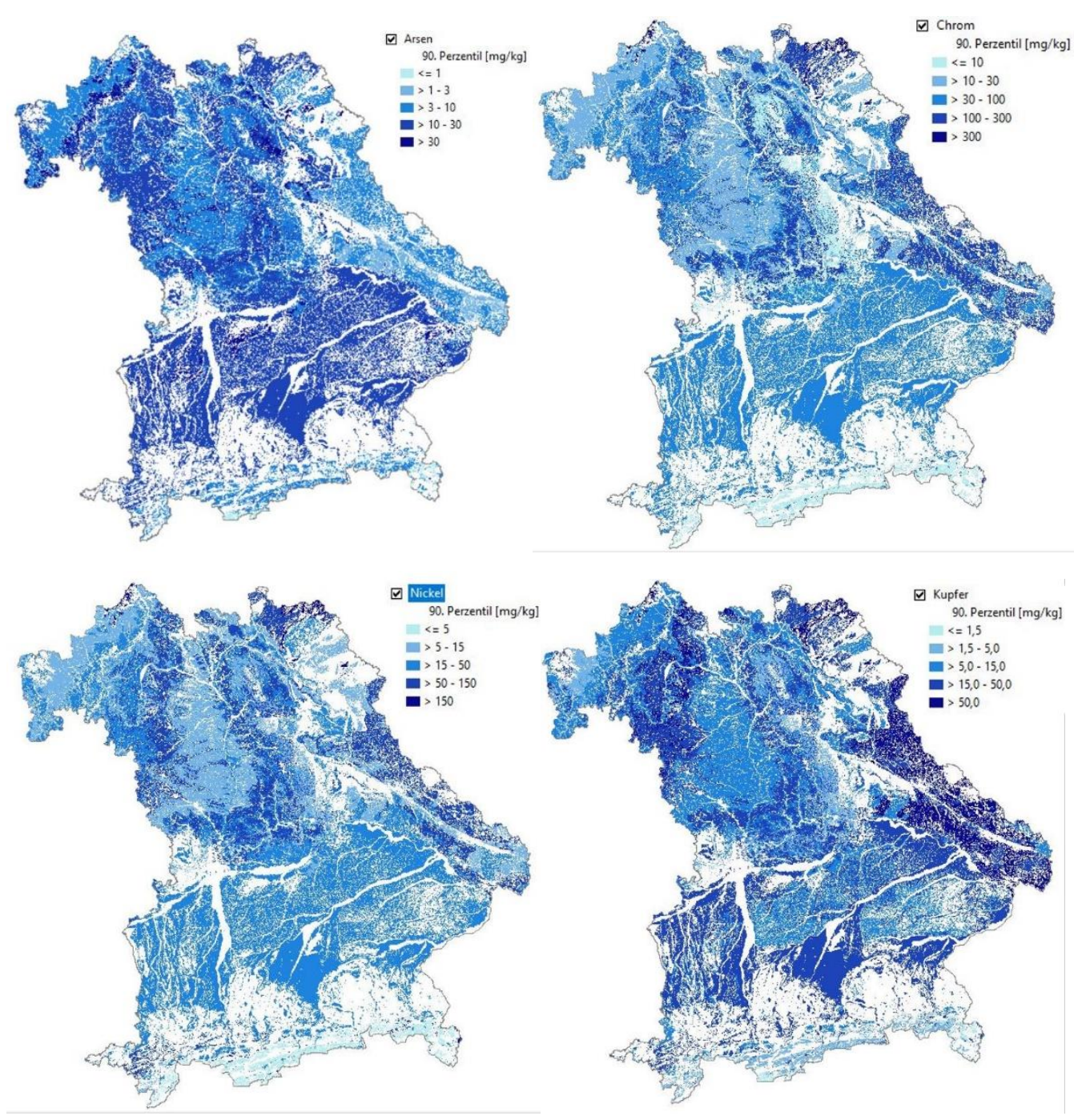

Fig. 4: Background values (90th percentile) of selected trace elements (arsenic, chromium, nickel and copper) of surface rocks of Bavaria. 

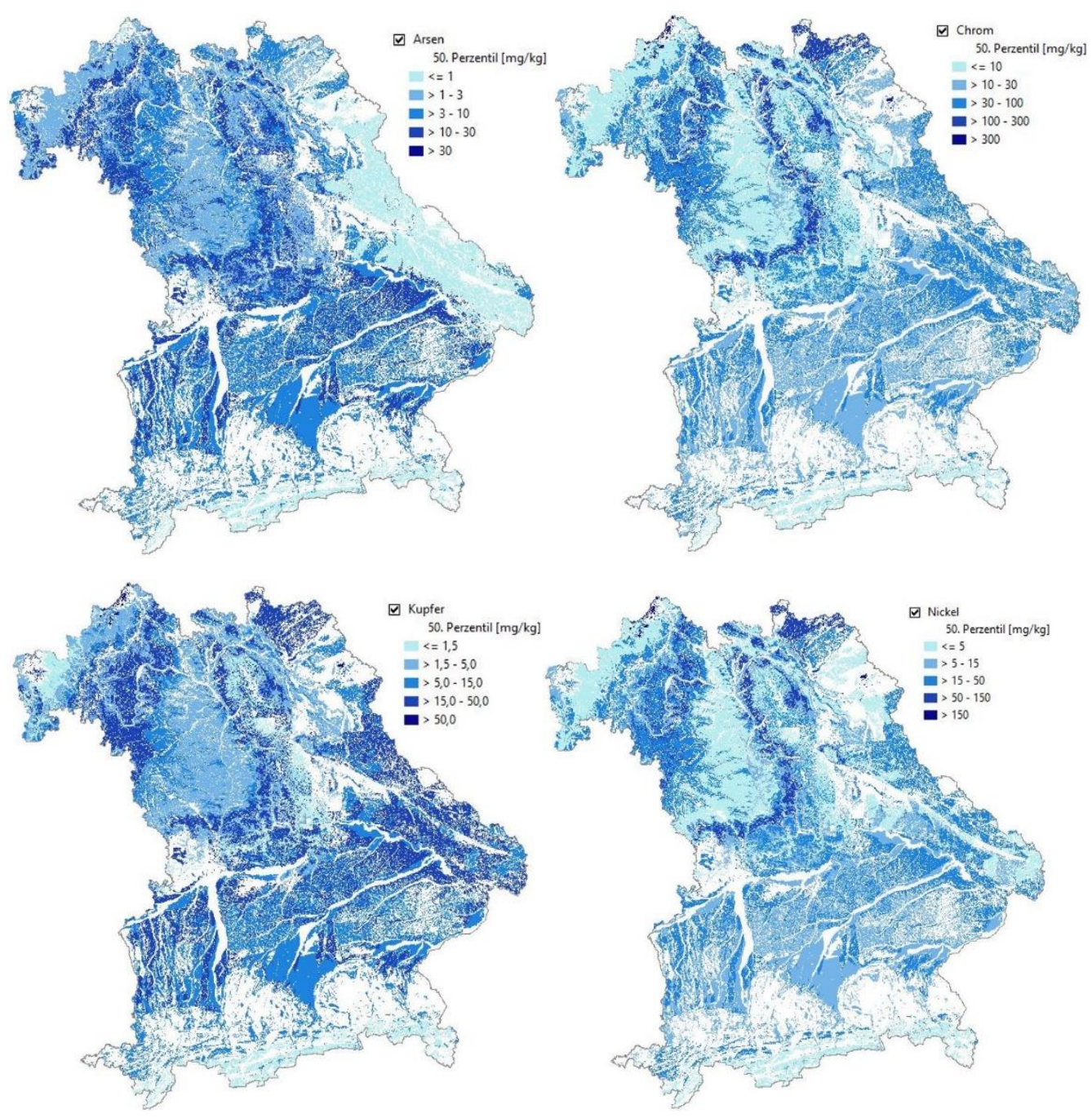

Fig. 5: Medians (50th percentile) of selected trace elements (arsenic, chromium, nickel and copper) of surface rocks of Bavaria.

\section{Discussion}

The geochemical background values of the lithogeochemical units of Bavaria were determined based on 8,838 samples of total content analysis for major and trace elements. The evaluation of concentration distributions showed that the majority of the distributions are lognormal. This allows the determination of valid ranges for most of the element distributions in the assigned units.

Due to the features of sampling and data, some constraints have to be taken into account. The minimum number of 10 samples within the normal distribution required for a statistical unit evaluation was not available for all of the 184 lithogeochemical units, so an area-wide 
evaluation was not yet performed. However, major elements could be evaluated for about $2 / 3$ of the area of Bavaria; for about $55 \%$ of the area trace element evaluations are available.

Statistical parameters given for lithogeochemical units always refer to defined lithologies and not to the chemical composition of the respective units as a whole. For example, if a unit consists of sandstones and mudstones, a seperate statistical evaluation was performed for these two lithologies. In the same way, element concentrations of unconsolidated rocks are determined with respect to different main grain size fractions (e.g. clay, silt, sand, gravel). The content of the geochemical database of the Bavarian Geological Survey was evaluated. The samples originate from a large time span (abt. Mid-80s to the present) and were taken from different projects with different objectives. Therefore, the dataset may have some limitations in terms of representativeness concerning analytical methods, detection limits, and sample distribution with respect to rock material selection. For example, mapping geologists may have been interested in determining the geochemical content of local features such as, for example, concretions or mineral precipitates rather than the predominant typical lithology. This issue was addressed by pre-selecting samples based on lithology and excluding concentration anomalies from the dataset.

Lithogeochemical units were formed by an aggregation of geological units in the geological map of Bavaria $(1: 25,000)$, based on the assumption, that the units have a similar geochemical composition. However, this basic assumption cannot be validated for geological units with too few samples. Therefore, the statistical analysis for some of the geological units may be biased to some degree.

Lithogeochemical units with highly variable lithologic compositions (such as sediments with a great variety of catchment areas like river sediments in a highly varied geological landscape), may have less significant element distributions. This can be easily seen by large ranges of the box-whisker plots of these units.

\section{Conclusions}

Most of the distributions of the elements under investigation are close to normal or lognormal distributions, with lognormal distributions clearly predominating. This permits the determination of valid characteristic distributions of element concentrations in the different delineated lithogeochemical units. 
Based on these findings, maps with typical background values of elements could be successfully produced on the basis of geological maps 1:25,000. These maps can serve for various applied uses, mainly for environmental purposes, such as:

- Soil protection: define areas with elevated geogenic background element concentrations and separate them from areas with anthropogenic influences

- Hydrogeology: correlate the hydrogeochemical composition of groundwater with the lithogeochemical background of aquifers

- Soil science: link soil geochemical composition to lithogeochemical properties of the underlying rocks

\section{Availability of data and material}

Additional material and data of the study not published in this paper are available from the corresponding author upon reasonable request.

\section{Code availability}

Not applicable.

\section{References}

Demitriades A, Smith DB, Wang X (2018) General concepts of geochemical mapping at global, regional, and local scales for mineral exploration and environmental purposes. Geochimica Brasiliensis 32/2:136-179. https://dx.doi.org/10.21715/GB2358-

\subsection{6}

Geuß U, Hangen E, Martin W (2011) Hintergrundwerte von anorganischen und organischen Schadstoffen in Böden Bayerns. UmweltSpezial, Bayerisches Landesamt für Umwelt, Augsburg, p 59.

https://www.lfu.bayern.de/boden/hintergrundwerte/doc/hintergrundwert_umweltspezial.pdf Accessed 6 July 2021

Helsel DR (2012) Statistics for censored environmental data using Minitab and R. 2nd edition, Wiley, New York, p 344

Lee L (2017) Package ,NADA“ - Nondetects and Data Analysis for Environmental Data. 64 p. https://cran.r-project.org/web/packages/NADA/NADA.pdf. Accessed 6 July 2021 
Lepeltier C (1969) A simplified statistical treatment of geochemical data by graphical representation. Economic Geology 64:538-550, Lancaster, PA

Licht OA (2020) Geochemical background - what a complex meaning has such a simple expression! Geochimica Brasiliensis 34/2:161-175. https://doi.org/10.21715/GB2358-

\section{$\underline{2812.2020342161}$}

Linhardt E, Zarbok P (2005) Geochemischer Atlas natürlicher Haupt-, Neben- und Spurenelemente der Gesteine Bayerns. Fachbericht, 24:188 p, Bayerisches Geologisches Landesamt, München. https://www.bestellen.bayern.de/shoplink/92024.htm Accessed 6 July 2021

Reimann C, de Caritat P (2016) Establishing geochemical background variation and threshold values for 59 elements in Australian surface soil. Science of the Total Environment 578:633648. http://dx.doi.org/10.1016/j.scitotenv.2016.11.010

Salminen R, Batista MJ, Bidovec M, Demetriades A, De Vivo B, De Vos W, Duris M, Gilucis A, Gregorauskiene V, Halamic J, Heitzmann P, Lima A, Jordan G, Klaver G, Klein P, Lis J, Locutura J, Marsina K, Mazreku A, O'Connor PJ, Olsson SÅ, Ottesen R-T, Petersell V, Plant JA, Reeder S, Salpeteur I, Sandström H, Siewers U, Steenfelt A, Tarvainen T (2005) Geochemical Atlas of Europe Part 1: Background Information, Methodology and Maps. Geological Survey of Finland. http://weppi.gtk.fi/publ/foregsatlas/index.php Accessed 6 July 2021

Sinclair AJ (1976) Applications of probability graphs in mineral exploration. The Association of Exploration Geochemists, Special Volume 4:95 p, Richmond Printers Ltd, Richmond Tammen A, Jung D, Wagner B, Wittenbecher M (2020) Lithogeochemische Hintergrundwerte der Gesteine Bayerns. UmweltSpezial, Bayerisches Landesamt für Umwelt, Augsburg, 173 p. https://www.bestellen.bayern.de/shoplink/lfu_bod_00172.htm Accessed 6 July 2021

De Vos WDE, Tarvainen T (2006) Geochemical Atlas of Europe. Part 2: Interpretation of Geochemical Maps, Additional Tables, Figures, Maps and Related Publications, Geological Survey of Finland, Espoo, 690 p. http://weppi.gtk.fi/publ/foregsatlas/part2.php Accessed 6 July 2021

Wagner B, Walter T, Himmelsbach T, Clos P, Beer A, Budziak D, Dreher T, Fritsche H-G, Hübschmann M, Marczinek S, Peters A, Poeser H, Schuster H, Steinel A, Wagner F, Wirsing 
G (2011) Hydrogeochemische Hintergrundwerte der Grundwässer Deutschlands als Web Map Service. Grundwasser 16/3:155-162, Springer, Berlin. https://doi.org/10.1007/s00767-011$\underline{0161-1}$

Walter T, Beer A, Brose D, Budziak D, Clos P, Dreher T, Fritsche H.-G, Hübschmann M, Marczinek S, Peters A, Poeser H, Schuster H, Wagner B, Wagner F, Wirsing G, Wolter R (2012) Determining natural background values with probability plots. Groundwater Quality Sustainability, IAH Selected Papers on Hydrogeology, CRC Press 26:331-341.

Zgłobicki W, Lata L, Plak A, Reszka M (2011) Geochemical and statistical approach to evaluate background concentrations of $\mathrm{Cd}, \mathrm{Cu}, \mathrm{Pb}$ and $\mathrm{Zn}$ (case study: Eastern Poland). Environ Earth Sci 62:347-355. https://doi.org/10.1007/s12665-010-0529-Z

\section{Acknowledgements}

This study was carried out as part of the project „Soil Atlas Bavaria“. The authors gratefully acknowledge funding of the project by the European Regional Development Fund (ERDF) in the funding period $2014-2020$ and by the Bavarian State Ministry for the Environment and Consumer Protection.

\section{Funding}

This study was jointly funded by the Bavarian State Ministry for the Environment and Consumer Protection and by the European Regional Development Fund (ERDF) in the funding period $2014-2020$.

\section{Author information}

\section{Affiliations}

\section{Bavarian Environment Agency, Hof, 95030, Germany}

Bernhard Wagner, Anneke Tammen, Dietmar Jung

\section{Contributions}

BW: Conceptualization; methodology; supervision; validation; writing-original draft; writingreview and editing. AT: Validation; methodology; data curation; formal analysis; investigation; software; visualization; writing-original draft. DJ: Supervision; validation; writing-original draft 


\section{Corresponding author}

Correspondence to Bernhard Wagner

\section{Conflicts of interest}

The authors declare that they have no conflict of interest. 